Жарок Анна Олександрівна, магістр психології, ПрАТ «ВНЗ «МАУП», 02000, вул. Фрометівська, 2, м. Київ, Україна

ORCID: https//orcid.org/0000-0002-2981-7714

Туриніна Олена Леонтіївна, кандидат психологічних наук, професор кафедри психології, ПрАТ «ВНЗ «МАУП», 02000, вул. Фрометівська, 2, м. Київ, Україна

ORCID: https//orcid.org/0000-0002-3810-2040

\title{
ПСИХОЛОГІЧНІ УМОВИ ЗАПОБІГАННЯ ЕМОЦІЙНОГО ВИГОРАННЯ ПСИХОЛОГІВ
}

\begin{abstract}
Анотація
Ключові слова: професія психолога, емоційне вигорання, психопрофілактика.

Постановка проблеми. Професія психолога несе в собі низку ризиків для особистості, зокрема, синдром емоційного вигорання, який створює умови неякісного консультування та може закріпити негативні тенденції для клієнтів.

Аналіз останніх досліджень i публікацій. Синдром емоційного вигорання - це вироблений особистістю механізм психологічного захисту, в вигляді повного або часткового виключення почуттів, у відповідь на певні психотравмуючі впливи, тісно пов'язаний із психосоматичним самопочуттям, а, відтак, станом, що передує хворобам. Проблемі емоційного вигорання присвятили свої праці такі дослідники, як В. В. Бойко, Л. М. Карамушка, Т. В. Темірова та ін., вони досліджували структурі елементи та змістову частину вигорання, визначали основні причини його виникнення, створювали психодіагностичну базу для дослідження, однак залишаються
\end{abstract}


значні прогалини в розумінні цього поширеного феномену в його основних факторах та проявах.

Формулювання мети статті. Мета полягає у виявленні особливостей емоційного вигорання в психологів та визначенні ефективних форм та методів роботи щодо його запобігання.

Виклад основного матеріалу. Емоційне вигорання негативно позначається на діяльності людини, оскільки призводить до емоційного та особистісного відчуження, невдоволеності собою, слідом за якими йдуть тривога, депресія, психосоматичні порушення, неадекватне емоційне реагування. За результатами дослідження було встановлено, що в групі психологів найвищий щабель цінностей посідають допомога іншому, спілкування та здоров’я, і в них сформована III фаза емоційного вигорання виснаження, інші дві перебувають на стадії формування.

Висновки та перспективи подальших досліджень. Розвиток емоційного вигорання спричиняє незадоволення основних потреб особистості, резонанс iз цінностями особистості та емоційною спрямованістю. Укладений нами комплекс заходів психологічної дії, забезпечує оптимальний корекційний та профілактичний ефект вигорання: фази вигорання призупинили свій розвиток та при продовження індивідуальної роботи мають змогу перейти в стадію не сформованості.

\section{Аннотация}

Жарок А. О., магистр психологии; Туринина Е. А., кандидат психологических наук, профессор кафедры психологии; ЧАО «ВУЗ «МАУП»; г. Киев, Украина. Психологические условия предотвращения эмоционального выгорания психологов.

Ключевые слова: профессия психолога, эмоциональное выгорание, психопрофилактика.

Постановка проблемы. Профессия психолога несет в себе ряд рисков для личности, в частности, синдром эмоционального выгорания, который 
создает условия некачественного консультирования и может закрепить негативные тенденции для клиентов.

Анализ последних исследований и публикаций. Синдром эмоционального выгорания - это выработанный личностью механизм психологической защиты, в виде полного или частичного исключения эмоций в ответ на определенные психотравмирующие воздействия, тесно связан с психосоматическим самочувствием, будучи состоянием, предшествующим болезни. Проблеме эмоционального выгорания посвящены работы таких исследователей, как: В. В. Бойко, Л. Н. Карамушка, Т. В. Темирова и др., Они исследовали структуре элементы и содержательной части выгорания, определяли основные причины его возникновения, создавали психодиагностическую базу для исследования, однако остаются значительные пробелы в понимании этого распространенного феномена в его основных факторах и проявлениях.

Формулировка цели статьи. Цель состоит в выявлении особенностей эмоционального выгорания у психологов и определении эффективных форм и методов работы по его предотвращению.

Изложение основного материала. Эмоциональное выгорание отрицательно сказывается на деятельности человека, так как приводит к эмоциональному и личностному отчуждению, неудовлетворенности собой, вслед за которыми следуют тревога, депрессия, психосоматические нарушения, неадекватное эмоциональное реагирование. По результатам исследования было установлено, что в группе психологов высшую ступень ценностей занимают помощь другому человеку, общение и здоровье, и у них сформирована III фаза эмоционального выгорания - истощение, другие две фазы находятся в стадии формирования.

Выводы и перспективы дальнейших исследований. Развитие эмоционального выгорания приводит к неудовлетворенности основных потребностей личности, резонируя с ценностями личности и эмоциональной направленностью. Разработанный нами комплекс мероприятий 
психологического воздействия, обеспечивает оптимальный коррекционный и профилактический эффект выгорания: фазы выгорания приостановили свое развитие и при продлении индивидуальной работы могут перейти в стадию несформированности.

\section{Annotation}

Zharok A. O., Magister of Psychology; Turinina E. A., PhD, Professor of the Department of Psychology; The Private Joint-Stock Company Higher Educational Institution Interregional Academy of Personnel Management; Kyiv, Ukraine.

\section{Psychological conditions to prevent burnout of psychologists.}

Key words: psychology profession, emotional burnout, psychoprophylaxis.

Formulation of the problem. The psychology profession carries a number of risks for an individual, in particular, a burnout syndrome, which creates conditions for poor counseling and can reinforce negative tendencies for clients.

Analysis of recent research and publications. The burnout syndrome is a psychological defense mechanism developed by the individual, in the form of complete or partial elimination of emotions in response to certain psycho-traumatic influences, is closely associated with psychosomatic well-being, being a state preceding the disease. The work of such researchers as: V. V. Boyko, L. N. Karamushka, T. V. Temirova and others are devoted to the problem of emotional burnout. They investigated the structure of the elements and the content of the burnout, determined the main causes of its occurrence, created the psychodiagnostic base for Studies, however, remain significant gaps in understanding this common phenomenon in its main factors and manifestations.

Formulation of the purpose of the article. The goal is to identify the features of emotional burnout in psychologists and to determine effective forms and methods of work to prevent it.

The presentation of the main material. Emotional burnout adversely affects human activity, as it leads to emotional and personal alienation, dissatisfaction with oneself, followed by anxiety, depression, psychosomatic 
disorders, and inadequate emotional response. According to the results of the study, it was found that in the group of psychologists the highest level of values is occupied by helping another person, communication and health, and they have formed the third phase of emotional burnout - exhaustion, the other two phases are in the formative stage.

Conclusions and prospects for further research. The development of emotional burnout leads to dissatisfaction with the basic needs of the individual, resonating with the values of the individual and emotional orientation. The complex of measures of psychological influence developed by us, provides the optimal corrective and preventive effect of burnout: the burnout phases have suspended their development and, if the individual work is extended, they can enter the unformed stage.

Ключові слова: професія психолога, емоційне вигорання, психопрофілактика.

Постановка проблеми. Професія психолога $є$ потрібною та незамінною, проте несе в собі низку ризиків для особистості, яка вирішила присвятити їй себе. Психологічні проблеми професійної діяльності психолога на сьогодні досліджуються активно. Проте неосяжним та незвіданим залишається синдром емоційного вигорання, який містить в собі руйнацію особи, зводить нанівець всю побудову передачі знань, створює умови неякісного консультування та може закріпити негативні тенденції для клієнтів.

Проблемі емоційного вигорання присвятили свої праці такі дослідники, як: В. В. Бойко, Л. М. Карамушка, Т.В. Темірова, Т.В. Зайчикова, I.А. Курапова, Н.М.Булатевич, В.С. Орел, Т. В. Н.С. Пряжников, М.В. Борисова, Н.В. Адаменко, Л. Помиткін, Х. Василькевич, І. Калашнік, С. Харченко та ін. Вони досліджували саме його структурі елементи та змістову частину вигорання, визначали основні причини виникнення, створювали 
психодіагностичну базу для дослідження. Але наявність значних прогалин у розумінні цього феномену в його основних факторах та проявах, а головне його розповсюдженість, потребує продовження дослідження.

Аналіз останніх досліджень та публікацій. Ретельний аналіз наукової літератури показав, що синдром емоційного вигорання - це вироблений особистістю механізм психологічного захисту у вигляді повного або часткового виключення почуттів (зниження їх енергетики) у відповідь на певні психотравмуючі впливи. Ми розглянули основні теорії синдрому емоційного вигорання і з'ясували, що єдиної і закінченої теорії немає. Дослідженням даного феномену займалися такі вчені, як :К. Маслач, В.В. Бойко, Т.В. Зайчикова, Р.С. Абрамова, В.Е Орьол і т.д. В наукових теоріях нашого часу, переважає розуміння феномену вигорання як багатогранного конструкту, набору негативних психологічних переживань, фізичного, емоційного та розумового виснаження від довготривалої напруги, пов’язаної 3 міжособистісними стосунками, які супроводжуються емоційною насиченістю та когнітивною складністю. Сучасні дослідження все частіше показують, що синдром емоційного вигорання тісно пов’язаний iз психосоматичним самопочуттям, а відтак, станом, що передує хворобам.

Аналіз факторів і симптомів синдрому емоційного вигорання дозволяє стверджувати, що емоційне вигорання негативно позначається на виконанні людиною своєї діяльності та відносинах з партнерами, оскільки призводить до емоційної і особистісної відстороненості, незадоволеності собою, слідом за якими йде тривога, депресія, психосоматичні порушення, неадекватне емоційне реагування.

Аналізуючи літературу щодо чинників виникнення синдрому емоційного вигорання, можна зробити висновок, що цей синдром формується в людей, які в силу своєї професії змушені постійно контактувати з іншими людьми, вислуховувати їх прохання, скарги, вимоги.

Розглянуто особливості синдрому емоційного вигорання В представників різних професій, таких як: медпрацівники, психологи, 
працівники сфери послуг, співробітники правоохоронних органів. Особливу увагу приділено феномену емоційного вигорання в психологів, адже вони мають специфічну роботу, що характеризується щоденним перевантаженням, самовіддачею, високою відповідальністю та дисбалансом між інтелектуально-енергетичними витримками й морально-матеріальною винагородою.

Як показав аналіз літератури, більшість науковців виділяють у психологів наступні ознаки «синдрому вигорання»:

- видозміни в поведінковій сфері (нерідко дивиться на годинник; посилюється опір виходу на роботу; нерідко запізнюється; втрачає творчі підходи до рішення заморочок та ін.);

- видозміни в емоційній сфері (спостерігається втрата почуття гумору; незмінне почуття біди, провини і самозвинувачення);

- видозміни в сфері мислення (більш конкретні думки про те, щоб кинути роботу; нездатність концентрувати увагу; ригідне мислення, що надає опір змінам; посилення підозрілості і недовірливості);

- видозміни в стані здоров'я (порушений сон; нерідкі, тривалі поточні малозначні захворювання; завищена чутливість до заразних хвороб; стомлюваність).

Формулювання мети статті. Об'єкт нашого дослідження - синдром емоційного вигорання як психологічний феномен. Предмет дослідження психологічні умови запобігання емоційного вигорання в психологів. Мета дослідження полягає у виявленні особливостей синдрому емоційного вигорання в психологів та визначенні ефективних форм та методів роботи щодо його запобігання.

Відповідно до поставленої мети, були визначені такі завдання:

1. На основі теоретичного аналізу, визначити передумови виникнення та розвитку синдрому емоційного вигорання в психологів.

2. Шляхом емпіричного дослідження визначити особливості синдрому емоційного вигорання в психологів. 
3. Визначити та впровадити ефективні форми та методи роботи щодо запобігання синдрому емоційного вигорання в психологів.

Виклад основного матеріалу. За результатами дослідження 45 осіб психологів-консультантів - нами було встановлено, що в респондентів цієї досліджуваної групи психологів сформована III фаза емоційного вигорання виснаження, інші дві фази перебувають на стадії формування. Дані психодіагностичних методик надають змогу визначити основні тенденції та особливості даної групи та особистостей. Проаналізуювавши дані первинного дослідження, можна стверджувати, що головними потребами досліджуваних психологів є гарні умови роботи, комфортна обстановка та відчуття потрібності, а також відчуття виконання корисної роботи. В них переважає тривожність та екстраверсія, відчуття незахищеності, та водночас вони прагнуть розширювати свої контакти, тобто, відкриті до спілкування та пізнання нового.

Для психологів, найвищий щабель цінностей посідають допомога іншому, спілкування та здоров'я, яке може свідчити проте, що на них покладають низку важливих завдань і вони несуть велику відповідальність.

Коли ми звернемо увагу на емоційну направленість особистості, то в досліджуваних психологів переважає альтруїстичність, тобто, потреба в допомозі та співпраці, а також комунікативний тип, для якого характерним $€$ потреба в спілкуванні та співпереживанні.

Спираючись на дане дослідження, можна припустити, що розвиток емоційного вигорання спричиняє незадоволення основних потреб особистості, резонанс із цінностями особистості та емоційною спрямованістю.

3 урахуванням проаналізованих наукових першоджерел, результатів проведеного психодіагностичного обстеження, нами був укладений комплекс відповідних заходів психологічної дії, проведена адаптація наявного тренінгу, що забезпечує оптимальний корекційний та профілактичний ефект щодо синдрому вигорання, та здійснена емпірична перевірка розробленого 
психологічного тренінгу. Теоретико-методичну основу організації програми тренінгу склали наукові положення Х. Василькевич щодо основ формування творчого потенціалу особистості психолога-практика та розвитку у фахівця психологічної служби мотиваційно-смислової регуляції його професійного становлення та вдосконалення [3].

Психологічний тренінг виступає як опосередкована інструментальна дія, в процесі якої учасники здобувають можливості привласнити набір «культурних знарядь» для оволодіння новою поведінкою. В процесі тренінгу, як інструментальної дії, виділяються наступні етапи: виведення 3 внутрішнього плану в зовнішній неконструктивних елементів і моделей поведінки; побудова моделі ідеальної поведінки в зовнішньому плані; модифікація поведінки учасників групи в бік максимального наближення до еталону і закріплення його у внутрішньому плані [6].

Тренінгова дія прямує на досягнення позитивних змін учасників, підвищення ступеню їх «конгруентності» 3 собою $\mathrm{i}$ навколишнім середовищем. У зв’язку з цим, нам найбільш близьке визначення тренінгу, що надає Н. Водоп'янова, яка підкреслює, що термін «тренінг» у структурі мови слід використовувати не для позначення методів навчання, а для позначення методів розвитку здібностей до навчання або оволодіння будьяким складним видом діяльності, зокрема, спілкуванням [4]. Крім того, що психологічний тренінг дозволяє розвивати здібності, він, до того ж, дозволяє підвищити якість взаємодії особистості з навколишнім світом. Тому нами було прийнято рішення в основі побудови програм профілактики і корекції вигорання використовувати психотренінгові технології.

Психологічний тренінг складався 33 модулів (рис. 1) та може бути адаптованим окремо під психологів різних сфер професійної діяльності. Комплексна програма містила в собі наступні основні напрямки: заходи організаційного та методичного забезпечення; практичні заходи щодо покращання професійно-психологічної підготовки (навчання, просвітництво); заходи щодо вдосконалення психологічного рівня (система соціально- 
психологічного вивчення та психологічного супроводження, попередження надзвичайних подій, формування здорового способу життя).

Проаналізувавши отримані результати психодіагностики двох досліджуваних груп, було виявлено, що показник групи А, за результатами методики «Діагностика емоційного вигорання» (В. В. Бойко), дає чітке розуміння ступеня розвитку емоційного вигорання в психологів, а також надає змогу прослідкувати по симптомах його проявлення. Так, в ході діагностування було виявлено наступі результати, представлені в таблицях 1-3.

Таблиця 1.

Результати дослідження особливостей емоційного вигорання I фази «Напруження» ( за методикою В. В. Бойко)

\begin{tabular}{|l|c|c|c|c|c|c|}
\hline \multirow{2}{*}{ Симптом } & \multicolumn{2}{|c|}{ Не сформувався } & \multicolumn{2}{|c|}{ Формується } & \multicolumn{2}{c|}{ Сформувався } \\
\cline { 2 - 7 } & \multicolumn{4}{|c|}{ Досліджувана група (кількість осіб у \%) } \\
\cline { 2 - 7 } & А & Б & А & Б & А & Б \\
\hline $\begin{array}{l}\text { Переживання } \\
\text { психотравмуючих } \\
\text { обставин }\end{array}$ & 40 & 20 & 33 & 47 & 27 & 33 \\
\hline $\begin{array}{l}\text { Незадоволеність } \\
\text { собою }\end{array}$ & 60 & 33 & 20 & 47 & 20 & 20 \\
\hline Загнаний у кут & 67 & 60 & 20 & 40 & 13 & 20 \\
\hline Тривога та депресія & 33 & 20 & 40 & 53 & 7 & 27 \\
\hline
\end{tabular}

Таблиця 2.

Результати дослідження особливостей емоційного вигорання II фази «Резистенція» ( за методикою В. В. Бойко)

\begin{tabular}{|c|c|c|c|c|c|c|c|}
\hline \multirow{2}{*}{ Симптом } & \multicolumn{2}{|c|}{$\begin{array}{c}\text { Не } \\
\text { сформувався }\end{array}$} & \multicolumn{2}{c|}{ Формується } & \multicolumn{2}{c|}{ Сформувався } \\
\cline { 2 - 7 } & \multicolumn{2}{|c|}{ Досліджувана група (кількість осіб у \%) } \\
\cline { 2 - 7 } & А & Б & А & Б & А & Б \\
\hline $\begin{array}{c}\text { Неадекватне вибіркове } \\
\text { емоційне реагування }\end{array}$ & 47 & 20 & 33 & 33 & 20 & 47 \\
\hline $\begin{array}{c}\text { Емоційно-моральна } \\
\text { дезорієнтація }\end{array}$ & 40 & 20 & 47 & 60 & 13 & 20 \\
\hline $\begin{array}{c}\text { Розширення сфери } \\
\text { економіі емоцій }\end{array}$ & 60 & 33 & 33 & 54 & 7 & 13 \\
\hline $\begin{array}{c}\text { Редукція професійних } \\
\text { обов'язків }\end{array}$ & 40 & 20 & 54 & 57 & 13 & 20 \\
\hline
\end{tabular}


Таблиця 3.

Результати дослідження особливостей емоційного вигорання III фази «Виснаження » ( за методикою В. В. Бойко)

\begin{tabular}{|c|c|c|c|c|c|c|}
\hline \multirow{2}{*}{ Симптом } & \multicolumn{3}{|c|}{ Не сформувався } & \multicolumn{2}{|c|}{ Формується } & \multicolumn{2}{|c|}{ Сформувався } \\
\cline { 2 - 7 } & А & Б & А & Б & А & Б \\
\cline { 2 - 7 } & 40 & 20 & 40 & 33 & 20 & 47 \\
\hline Емоційний дефіцит & 33 & 20 & 47 & 47 & 20 & 33 \\
\hline $\begin{array}{c}\text { Емоційне } \\
\text { відокремлення }\end{array}$ & 33 & 13 & 47 & 40 & 13 & 47 \\
\hline $\begin{array}{c}\text { Особистісне } \\
\text { відчуження } \\
\text { (деперсоналізація) }\end{array}$ & 60 & 37 & 33 & 53 & 7 & 13 \\
\hline $\begin{array}{c}\text { Психосоматичні та } \\
\text { психовегетативні } \\
\text { порушення }\end{array}$ & & & & & \\
\hline
\end{tabular}

Так, методика «Діагностика емоційного вигорання » надала змогу виявити, що в групі А (група, яка брала участь в індивідуальній та груповій роботі), не має сформованої фази емоційного синдрому. III фаза «виснаження», яка при первинному діагностуванні мала була сформована, пішла на спад і має стадію формування, а всі інші фази, тобто «напруження» та «резистенція» перебувають на стадії формування, але вже в меншої кількості психологів. Тобто, можна припустити, що фази призупинили свій розвиток та при продовженні індивідуальної роботи над собою можуть перейти в стадію несформованості.

Якщо поглянути на результати групи Б, то ситуація наступна: III фаза сформована, а I та II фаза мають такі самі показники, тобто, перебувають на стадії формування. Отже, можна стверджувати, що в даної групи сидром емоційного вигорання продовжує поетапно формуватись.

Якщо звернутися до аналізу симптомів, то можна прослідкувати наступне:

- Фаза «напруження»,- то варто зазначити, що у груп А має такі показники, як: у $27 \%$ досліджуваних осіб симптом «переживання психотравмуючих обставин» сформований, а у 33\% він перебуває в стадії формування - це вказує на те, що психологи почали спостерігати на собі 
вплив психотравмуючих чинників професії. Проте, варто зазначити, що в 40\% психологів цей симптом перебуває на стадії несформованості. Симптом «тривоги та депресії», який проявляється тривожно-депресивною симптоматикою, що відноситься до сфери професійної діяльності, а саме: почуття незадоволеності діяльністю і собою, що породжує велику напругу,виявився сформованим лише в 20 \% досліджуваних психологів, а ще в 20 \% осіб він знаходиться на стадії формування. Ці показники свідчать, що в 60\% він перебуває на стадії несформованості. В 20 \% психологів «незадоволеність собою», що проявляється у відчуттях незадоволеності собою, обраною професією, посадою, розвивається при неможливості конструктивного вирішення ситуації, перебуває на стадії сформованості, тоді як також у 20 \% осіб даний елемент формується, а в 60\% досліджуваних психологів - не сформований. Симптом «загнаний у кут», для якого характерним є відчуття безвиході, що розвивається при марних спробах усунути тиск психотравмуючих обставин,- це стан «інтелектуально-емоційного затору». Цей симптом не сформований у 67\% досліджуваних осіб, проявляється в 13\% досліджуваних як сформований симптом, а в 40 \% досліджуваних він перебуває на стадії формування.

Якщо звернутися до результатів дослідження групи Б, то ми можемо прослідкувати наступне: в $33 \%$ осіб симптом «переживання психотравмуючих обставин» сформований, а в 47\% він перебуває в стадії формування - це вказує на те, що психологи почали спостерігати на собі вплив психотравмуючих чинників професії. Симптом «тривоги та депресії», який проявляється тривожно-депресивною симптоматикою, яка відноситься до сфери професійної діяльності, а саме: почуття незадоволеності діяльністю і собою, що породжує велику напругу,- сформованим виявився в 20\%, а в 47\% досліджуваних осіб він знаходиться на стадії формування. В досліджуваних психологів виявлено також симптом «незадоволеність собою», що проявляється у відчуттях незадоволеності собою, обраною професією, посадою, розвивається при неможливості конструктивного 
вирішення ситуації та в 20\% досліджуваних перебуває на стадії сформованості, а в 47 \% респондентів даний елемент формується. Симптом «загнаний у кут», для якого характерно відчуття безвиході, що розвивається при марних спробах усунути натиск психотравмуючих обставин, - це стан «інтелектуально-емоційного затору», який в $20 \%$ досліджуваних проявляється як сформований, а в 40\% досліджуваних - перебуває на стадії формування.

Фаза «резистенція», яка відповідає за формування захисту від надмірної перевтоми,- за результатами групи А, в 47\% опитаних виявлено симптом «неадекватне вибіркове емоційне реагування», що спостерігається у випадках, коли професіонал перестає вловлювати різницю між двома явищами, що принципово відрізняються, та характеризується економним проявом емоцій і неадекватним вибірковим емоційним реагуванням. Тобто, професіонал неадекватно «економить» на емоціях, обмежує емоційну віддачу за рахунок вибіркового реагування на ситуації суб'єктів діяльності; емоційний контакт встановлюється не з усіма суб’єктами, а за принципом «хочу-не хочу» - неадекватним або вибірковим чином. Даний симптом в 47\% не сформований, у 33 \% респондентів - формується, а у 20 \% - сформований. Симптом «емоційно-моральна дезорієнтація» сформований у $13 \%$ досліджуваних психологів, у 47 \% - він перебуває на стадії формування, а в $40 \%$ - не сформований. Він виявляється в тому, що у працівника емоції не спонукають або недостатньо стимулюють етичні відчуття. Показник «редукція професійних обов’язків», що виявляється в спробах полегшити або скоротити обов’язки, які вимагають емоційних витрат, сформований в 7 \%, а у 33\% осіб - у стадії формування, проте в $60 \%$ - не сформований. Розширення сфери економії емоцій не сформоване лише в 40\% осіб, тоді яу в $54 \%$ цей симптом перебуває в фазі формування, а в 13\% він є вже сформованим. Даний симптом розвивається, коли на роботі фахівець так втомлюється від контактів, розмов, відповідей на запитання, що йому не хочеться спілкуватися навіть із близькими. 
В досліджуваній групі Б ми можемо прослідкувати, що в 47\% опитаних спостерігається симптом «неадекватне вибіркове емоційне реагування», що спостерігається у випадках, коли професіонал перестає уловлювати різницю між двома явищами, що принципово відрізняються: економним проявом емоцій $\mathrm{i}$ неадекватним вибірковим емоційним реагуванням. Тобто, професіонал неадекватно «економить» на емоціях, обмежує емоційну віддачу за рахунок вибіркового реагування на ситуації суб’єктів діяльності; емоційний контакт встановлюється не 3 усіма суб’єктами, а за принципом «хочу-не хочу» - неадекватним або вибірковим чином. Даний симптом у групі Б сформований у 53\%, в 47 \% респондентів формується. Симптом «емоційно-моральна дезорієнтація», що виявляється в тому, що у працівника емоції не спонукають або не достатньо стимулюють етичні відчуття, сформований у 20\% психологів групи Б, в $60 \%$ - він перебуває на стадії формування. Показник «редукція професійних обов'язків», що виявляється в спробах полегшити або скоротити обов'язки, які вимагають емоційних витрат, сформований у групі Б в 20\%, а у 57 \% осіб - у стадії формування. Симптом «розширення сфери економії емоції» в 54 \% перебуває на фазі формування, а у 13 \% він уже сформований.

«Виснаження» - третя фаза, що вказує на виражені падіння загального тонусу і ослабленням нервової системи, а емоційний захист стає невід'ємним атрибутом особи у досліджуваних виявився сформованим, у 55 \% осіб він наявний, а у $25 \%$ досліджуваних він на стадії формування.

В групі А симптом «емоційний дефект», для якого $є$ характерним відчуття, що емоційно професіонал вже не може допомогти суб'єктам своєї діяльності, також виявляє менший прояв позитивних емоцій і частіше негативних, наприклад, різкість, дратівливість,- виявлено сформованим у $20 \%$ психологів, у 40\% він знаходиться на стадії формування, а в $40 \%$ досліджуваних він не сформований. Симптом «особистісного відчуження», для якого характерним $є$ те, що працівник майже повністю виключає емоції зі сфери своєї професійної діяльності, сформований у 13 \% осіб, у 47\% - 
формується, а у 33\% осіб не сформований. «Емоційне відокремлення», для якого характерне те, що відчувається повна або часткова втрата інтересу до людини, було визначено, що він не сформований у 33\%, а перебуває на стадії формування у 47\% досліджуваних, у 20 \% досліджуваних він сформувався. Симптом «психосоматичні та психовегетативні порушення», що проявляється на рівні психічного і фізичного самопочуття, сформувався лишее в 7\% досліджуваних.

У групі Б симптом «емоційний дефект», для якого характерним відчуття, що емоційно професіонал вже не може допомогти суб'єктам своєї діяльності, також виявляє менший прояв позитивних емоцій і частіше проявляються негативні, наприклад, різкість, дратівливість. Цей симптом виявлено сформованим у 47\% психологів даної групи, в 33\% він знаходиться на стадії формування. Симптом «особистісного відчуження», для якого характерним є те, що працівник майже повністю виключає емоції зі сфери своєї професійної діяльності, сформований у 47\% осіб групи Б, а в 47\% формується. «Емоційне відокремлення», при якому відчувається повна або часткова втрата інтересу до людини, виявиася сформованим у 33\%, а перебуває на стадії формування у 47\% досліджуваних цієї групи. Симптом «психосоматичні та психовегетативні порушення», що проявляється на рівні психічного i фізичного самопочуття, в групі Б сформувався в $13 \%$ досліджуваних, а в 53\% - формується.

Основними формами психокорекції синдрому емоційного вигорання у психологів є індивідуальна та групова. До індивідуальної форми можна віднести індивідуальні консультації. Ї̈̈ плюси полягають у тому, що психолог може не боятись оцінки з іншої сторони, осуду чи розголошення. Він перебуває зі своїми думками та намагається спираються на власний досвід виробити та знайти певні захисні механізми.

Перевага групових форм полягає в тому, що в процесі їх проведення отримується різноманітний зворотний зв'язок та відбувається апробація 
набутих навичок спілкування, відпрацьовується альтернативні форми поведінки та соціальна взаємодія.

На індивідуальних консультаціях діяльність була направлена на стабілізацію основних сфер людини : емоційно-вольову, фізіологічну та ціннісно-орієнтовну. Групова робота в собі містила роботу за програмою «Шлях до самого себе». Програма психокорекції дала змогу розглянути всі спектри власного життя.

Дані вторинного діагностування засвідчили наступне :

- По-перше - в групі А (група, яка брала участь в індивідуальній та груповій роботі), не має сформованої фази емоційного синдрому. III фаза «виснаження», яка при первинному діагностуванні мала була сформована, пішла на спад і має стадію формування, а всі інші фази, тобто «напруження» та «резистенція» перебувають на стадії формування, але уже у меншої кількості психологів. Тобто можна зробити висновок, що фази призупинили свій розвиток та при продовження індивідуальній роботі над собою мають змогу перейти а стадію не сформованості. Якщо поглянути на результати групи Б, то ситуація наступна: III фаза сформована, і I та II фаза має ті самі показники, тобто перебувають на стадії сформування. Отже, можна стверджувати, що у даної групи сидром емоційного вигорання продовжує поетапно сформуватись.

- По-друге - дані інших методик дали змогу прослідкувати те, що дані заходи не втручаються в ціннісну, мотиваційну та емоційну спрямованість особистість .

- По - третє - виявилися зміни в індивідуально-типологічній структурі, так в групі А зменшились показники домінування тривожності та агресивності.

Висновки та перспективи подальших досліджень. Розвиток емоційного вигорання спричиняє незадоволення основних потреб особистості, резонанс iз цінностями особистості та емоційною спрямованістю. Укладений нами комплекс заходів психологічної дії, 
забезпечує оптимальний корекційний та профілактичний ефект вигорання: фази вигорання призупинили свій розвиток та при продовження індивідуальної роботи мають змогу перейти в стадію не сформованості.

\section{Список використаних джерел}

1. Бойко В. В. Синдром «емоційного вигорання» в професійному спілкуванні / В. В. Бойко. - СПб.: Пітер. 1999.- 434с.

2. Борисова M. В. Основні напрями профілактики та корекції професійного вигорання / Борисова М. В., Анісімова Н.П. // Ярославський педагогічний вісник- 2011 - № 2 - Т. II (Психолого-педагогічні науки). - С. 212-215.

3. Василькевич X. М. Трудоголізм як чинник виникнення синдрому психічного вигорання психолога / Х. М.Василькевич //Науковий часопис Національного педагогічного університету імені М. П. Драгоманова. Київ:НПУ, 2007. - Вип.19(43) - С.21-43.

4. Водоп'янова Н. Є. Синдром вигорання: діагностика і профилактика / Водоп'янова Н. С., Старченкова Є.С.- СПб.: Пітер, 2008.- 336 с.

5. Грисенко Н. В. Формування позитивних цінностей та відповідних їм «сильних» рис особистості як фактори попередження емоційного вигорання психолога та збереження здоров'я суб'єктів психологічного процесу [Електронний ресурс].-режим доступу: http://virtkafedra.ucoz.ua /ik4/Grysenko.pdf

6. Міщенко М. С. Особливості синдрому емоційного вигорання [Електронний ресурс].-Режим доступу: http://dspace.udpu.org.ua:8080/ jspui/bitstream/6789/415/1/Mischenko_M.C..pdf

\section{References}

1. Boyko, V.V. (1999), Syndrom «emotsiynoho vyhorannya» v profesiynomu spilkuvanni [The syndrome of "emotional burnout" in professional communication], Piter, $\mathrm{SPb}$, Russia. 
2. Borysova, M.V. and Anisimova, N.P. (2011)"Main directions of prevention and correction of professional burnout", Yaroslavs'kyy pedahohichnyy visnyk, vol. 2, T. II, pp. 212-215.

3. Vasyl'kevych, Kh.M. (2007), "Laborogolizm as a factor in the emergence of a syndrome of mental burnout of a psychologist", Naukovyy chasopys Natsional'noho pedahohichnoho universytetu imeni M. P. Drahomanova, vol.19(43), pp.21-43.

4. Vodop'yanova, N.Ye. and Starchenkova, Ye.N. (2008) Syndrom vyhorannya: diahnostyka i profylaktyka [Burning Syndrome: Diagnosis and Prevention], Piter, $\mathrm{SPb}$, Russia.

5. Hrysenko, N.V. "Formation of positive values and corresponding "strong" personality traits as factors of prevention of emotional burnout of a psychologist and preservation of health of subjects of the psychological" [Online], available at: http://virtkafedra.ucoz.ua /ik4/Grysenko.pdf

6. Mishchenko, M.S. "Features of the emotional burnout syndrome" [Online], available at: http://dspace.udpu.org.ua:8080/jspui/bitstream/6789/415/1/ Mischenko_M.C..pdf 